\title{
Rapid-onset oral isotretinoin-induced acne fulminans without systemic symptoms in a male adolescent
}

\section{Pinar Incel Uysal}

\author{
Department of Dermatology and Venerology, Faculty of Medicine, TOBB Economics and Technology University, Ankara, \\ Turkey
}

Corresponding author: Pinar Incel Uysal, MD, Assoc. Prof. E-mail: pinarincel@hotmail.com

\begin{abstract}
Isotretinoin-induced acne fulminans without systemic symptoms (IIAF-WOSS) is an uncommon clinical variant of acne, not exhibiting systemic symptoms but with potentially severe skin lesions. Some authors believe that its occurrence is dose-dependent. Herein, we present the case of a sixteen-year-old boy with IIAF-WOSS, which developed two weeks after starting treatment with isotretinoin $0.6 \mathrm{mg} / \mathrm{kg} /$ day. The patient was successfully treated with a systemic steroid. IIAF-WOSS may cause significant disfiguring scarring, thus the physician needs to be aware of this condition, even early with low doses of isotretinoin.
\end{abstract}

Key words: Acne; Acne fulminans; Oral isotretinoin

\section{INTRODUCTION}

Acne fulminans (AF) is a rare and severe variant of inflammatory acne characterized by abrupt-onset nodules, painful erosions, and hemorrhagic crusts. Systemic symptoms, including fever, malaise, and arthralgias, may develop in its most severe forms. Isotretinoin-induced AF without systemic symptoms (IIAF-WOSS) is increasing in frequency due to widespread use of the drug.

\section{CASE REPORT}

A sixteen-year-old boy, weighing $47 \mathrm{~kg}$, presented with abrupt-onset papulopustular lesions, nodules, and crusts present for one week. The patient was treated elsewhere with oral isotretinoin $30 \mathrm{mg}$ daily for sixteen days. A dermatologic examination revealed thick, yellow, crusty, and hemorrhagic pustules and nodules on the forehead, cheeks, and jawline (Fig. 1). There were no triggering factors and no other systemic symptoms. Laboratory parameters were within normal limits. The patient was evaluated as having IIAF-WOSS and the oral isotretinoin treatment was discontinued. Systemic corticosteroid treatment (oral methylprednisolone at a dose of
$0.5 \mathrm{mg} / \mathrm{kg} /$ day) was initiated. Due to the persistence of the crusted lesions in week two of the treatment, the dose was increased to $0.8 \mathrm{mg} / \mathrm{kg} /$ day. Once the lesions began healing in week two of $0.8 \mathrm{mg} / \mathrm{kg} /$ day doses, oral isotretinoin $0.1 \mathrm{mg} /$ day was restarted. After four weeks at the same dose, the oral corticosteroid dose was tapered and isotretinoin was gradually increased to a tolerable level $(20 \mathrm{mg} /$ day). The lesions healed almost completely with scarring in the following four weeks (Fig. 2).

\section{DISCUSSION}

IIAF-WOSS is a recently described term for sudden worsening of acne in patients with acne vulgaris treated

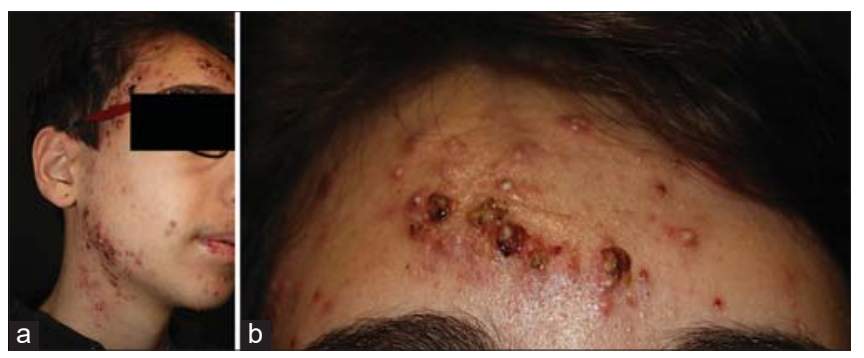

Figure 1: (a) The initial presentation of the patient. (b) A closer view of the lesions.

\footnotetext{
How to cite this article: Incel Uysal P. Rapid-onset oral isotretinoin-induced acne fulminans without systemic symptoms in a male adolescent. Our Dermatol Online. 2021;12(4):417-418.

Submission: 19.02.2021; Acceptance: 07.05.2021

DOI: 10.7241/ourd.20214.14
} 


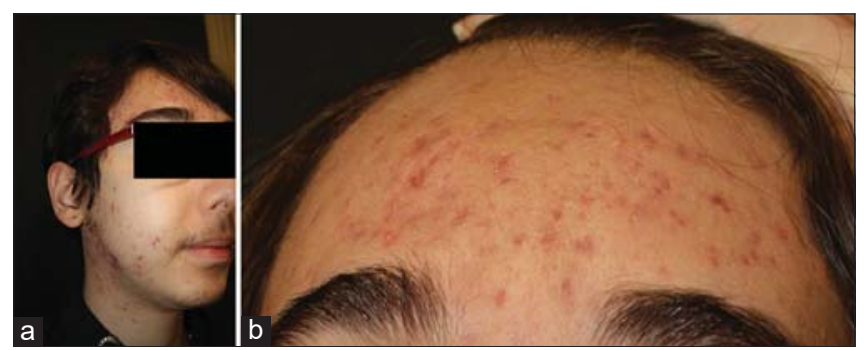

Figure 2: (a) The marked improvement at the end of twelve weeks of treatment (b) Rolling and boxcar scars seen after the resolution of the inflammatory lesions.

with oral isotretinoin. Male adolescents are more likely to be affected.

Our patient, who presented a mild form of IIAF-WOSS, was using a subtotal dose of isotretinoin $(0.6 \mathrm{mg} / \mathrm{kg} /$ day) before presentation. In fact, the literature offers several reports suggesting an association of $\mathrm{AF}$ with a very low dose $(0.1 \mathrm{mg} / \mathrm{kg} /$ day $)$ of isotretinoin [1]. These lesions have been reported to usually develop between the fourth and eighth week of treatment. In our patient, the occurrence was earlier than expected. This may be due to the fact that the patient was underweight (with a body mass index of $17.2 \mathrm{~kg} / \mathrm{m}^{2}$ ).

The treatment mainly depends on the severity of the clinical manifestations. Our patient was treated according to the recommendations of an evidencebased expert panel [2]. This study is comprehensive guidance for the management of $\mathrm{AF}$ and its variants. Given the sine fulminant clinical presentation of the patient, he was initially treated with a minimally effective dose of $0.5 \mathrm{mg} / \mathrm{kg} /$ day. Because there was no clinical improvement during the follow-up period, the dose was increased to $0.8 \mathrm{mg} / \mathrm{kg} / \mathrm{day}$. There are several remarkable reports of IIAF with aberrant granulation tissue and subsequent scarring in the literature $[3,4]$. Despite the absence of systemic symptoms and large and/or widespread necrotic lesions in our patient, corticosteroid therapy for twelve weeks was required. Unfortunately, IIAF-WOSS appears to be increasing in recent years. As some authors suggest, clinicians seem to be more familiar with these indolent forms, leading to more recognition and preventing truly fulminant acne forms [5]. However, there is still a paucity of studies addressing the optimal management of this rare entity.

\section{CONCLUSION}

Considering the major psychosocial impacts of adolescence, further studies are required to determine the predisposing factors and the optimal management strategies for this rare condition that leads to undesirable, disfiguring scars.

\section{ACKNOWLEDGMENTS}

Written consent was obtained from the patient.

\section{Consent}

The examination of the patient was conducted according to the principles of the Declaration of Helsinki.

The authors certify that they have obtained all appropriate patient consent forms, in which the patients gave their consent for images and other clinical information to be included in the journal. The patients understand that their names and initials will not be published and due effort will be made to conceal their identity, but that anonymity cannot be guaranteed.

\section{REFERENCES}

1. Fakih A, Goens J, Grozdev I, Dangoisse C, Richert B. Acne fulminans induced by a low dose isotretinoin: Case report and review of the literature. Dermatol Online J. 2020;26.

2. Greywal T, Zaenglein AL, Baldwin HE, Bhatia N, Chernoff KA, Del Rosso JQ, et al. Evidence-based recommendations for the management of acne fulminans and its variants. J Am Acad Dermatol. 2017;77:109-17.

3. Robertson DB, Kubiak E, Gomez EC. Excess granulation tissue responses associated with isotretinoin therapy. Br J Dermatol. 1984;111:689-94.

4. Li AW, Antaya RJ. Isotretinoin-induced acne fulminans without systemic symptoms with concurrent exuberant granulation tissue. Pediatr Dermatol. 2018;35:257-8.

5. Zaba R, Schwartz R, Jarmuda S, Czarnecka-Operacz M, Silny W. Acne fulminans: Explosive systemic form of acne. J Eur Acad Dermatol Venereol. 2011;25:501-7.

Copyright by Incel Uysal Pinar. This is an open access article distributed under the terms of the Creative Commons Attribution License, which permits unrestricted use, distribution, and reproduction in any medium, provided the original author and source are credited.

Source of Support: Nil, Conflict of Interest: None declared. 